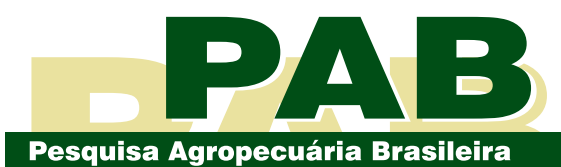

ISSN 1678-3921

Journal homepage: www.embrapa.br/pab

For manuscript submission and journal contents, access: www.scielo.br/pab

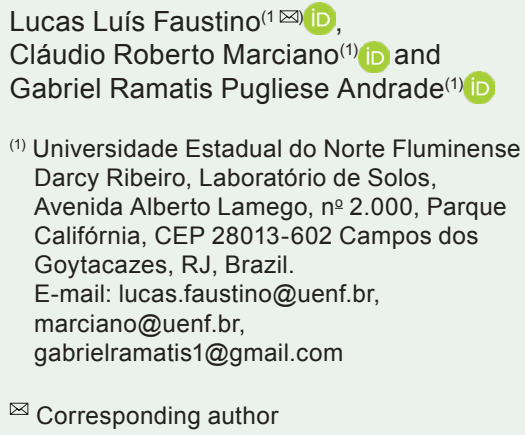

(1) Universidade Estadual do Norte Fluminense Darcy Ribeiro, Laboratório de Solos, Avenida Alberto Lamego, № 2.000, Parque Califórnia, CEP 28013-602 Campos dos Goytacazes, RJ, Brazil.

\section{Physical quality of soil under secondary forest, leguminous trees, and degraded pasture}

\begin{abstract}
The objective of this work was to assess the efficiency of revegetation with forest leguminous species, for the recovery of the physical quality of a Typic Hapludult under degraded pasture, located in a steep-slope tropical landscape in Southeastern Brazil. Soil samples were collected at the $0-0.10 \mathrm{~m}$ and $0.10-0.20 \mathrm{~m}$ depths, in areas under Acacia auriculiformis (northern black wattle), Mimosa caesalpiniifolia ("sabiá"), Inga edulis ("ingá"), secondary forest ("capoeira"), and degraded pasture. Tensile strength (TS) was evaluated in soil aggregates of the size classes $8.0-12.5 \mathrm{~mm}$ and $12.5-19.0 \mathrm{~mm}$, for the variables TS 8 and TS 12.5, respectively. The lowest mean values of both variables always occurred under the pasture cover (TS 8 of $37.1 \mathrm{kPa}$ and TS 12.5 of $22.7 \mathrm{kPa}$, for the $0-0.10 \mathrm{~m}$ soil layer; and TS 8 of $39.2 \mathrm{kPa}$ and TS 12.5 of $22.8 \mathrm{kPa}$, for the $0.10-0.20 \mathrm{~m}$ soil layer). The highest TS mean values were obtained under the "capoeira" cover (TS 8 of $62.2 \mathrm{kPa}$, for the $0-0.10 \mathrm{~m}$ soil layer) and "sabiá" cover (TS 12.5 of $46.0 \mathrm{kPa}$, for the $0-0.10 \mathrm{~m}$ soil layer; and TS 8 of $53.0 \mathrm{kPa}$ and TS 12.5 of $51.4 \mathrm{kPa}$, for the $0.10-0.20 \mathrm{~m}$ soil layer). Land revegetation with leguminous trees recovers the soil physical quality, since the TS values under the evaluated covers are predominantly closer to those of the secondary forest than to those of the degraded pasture.
\end{abstract}

Index terms: Acacia auriculiformis, Inga edulis, Mimosa caesalpiniifolia, soil aggregate, tensile strength.

\section{Qualidade física do solo sob floresta secundária, leguminosas arbóreas e pastagem degradada}

Resumo - O objetivo deste trabalho foi avaliar a eficiência da revegetação com espécies leguminosas florestais, para a recuperação da qualidade física de um Argissolo Vermelho-Amarelo sob pastagem degradada, localizado em uma paisagem tropical de declive acentuado no Sudeste brasileiro. Amostras de solo foram coletadas nas profundidades de 0-0,10 e 0,10-0,20 m em áreas sob Acacia auriculiformis (acácia), Mimosa caesalpiniifolia (sabiá), Inga edulis (ingá), floresta secundária (capoeira) e pastagem degradada. A resistência tênsil(TS) foi avaliada em agregados das classes de tamanhos de 8,0-12,5 e de 12,5-19,0 mm para as variáveis TS 8 e TS 12.5 , respectivamente. Os menores valores médios dessas duas variáveis ocorreram sempre sob pastagem (TS 8 de 37,1 kPa e TS 12.5 de $22,7 \mathrm{kPa}$, para a camada de $0-0,10 \mathrm{~m}$; e TS 8 de 39,2 kPa e TS 12.5 de $22,8 \mathrm{kPa}$, para a camada de $0,10-0,20 \mathrm{~m}$ ). As maiores médias foram obtidas sob capoeira (TS 8 de 62,2 $\mathrm{kPa}$, para a camada de $0-0,10 \mathrm{~m}$ ) e sabiá (TS 12.5 de 46,0 kPa, para a camada de $0-0,10 \mathrm{~m}$; e TS 8 de 53,0 kPa e TS 12.5 de 51,4 $\mathrm{kPa}$, para a camada de $0,10-0,20 \mathrm{~m}$ ). A revegetação de terras com leguminosas arbóreas recupera a qualidade física do solo, uma vez que os valores de TS sob essas coberturas apresentam-se predominantemente mais próximos dos TS da floresta secundária do que dos da pastagem degradada.

Termos para indexação: Acacia auriculiformis, Inga edulis, Mimosa caesalpiniifolia, agregado do solo, resistência tênsil. 


\section{Introduction}

Soil structure is one of the most important attributes related to soil productivity and quality, helping the ecosystems to guarantee water flow and quality, biodiversity, and a good atmospheric gas balance (Cardoso et al., 2013). However, under the current model of dominant unsustainable agricultural production, human activities have affected the soil physical properties, leading to increasing soil erosion rates and consequent contamination of water bodies, which reduce the productivity of natural and agricultural ecosystems (Prety \& Bharucha, 2014).

The northern Rio de Janeiro state in Brazil is highly affected by unsustainable agricultural practices. The original Atlantic coast forest cover has been reduced by $5 \%$ and replaced by agricultural crops, mainly by poorly managed pastures, low-technology intensive cultivation of sugarcane (Gama-Rodrigues et al., 2008; Gomes et al., 2018). Thus, many of the potentially productive land areas are degraded or under degradation risk.

An alternative to reclaim the soil physical properties affected by unsustainable management is to use leguminous trees. These tree species are nitrogen fixers that have the capacity to increase the organic matter content and the availability of nutrients, and to improve the soil physical properties (Manhães et al., 2013; Resende et al., 2013; Gomes et al., 2018). Grasses can also play a very important role in the continuous addition of soil organic matter when correctly managed. In this case, their root system improve the formation of soil aggregates (Santos et al., 2012), and greatly increase the biomass inputs in surface soil layers, improving other soil physical properties.

The effects of revegetation on the recovery of degraded lands can be evaluated by measuring the soil properties associated with soil quality. The benefits of the leguminous trees northern black wattle (Acacia auriculiformis A. Cunn. ex Benth.) and "sabiá" (Mimosa caesalpiniifolia Benth.), in the area of the present study, have been verified for biological aspects, such as the increasing microbial activity and the abundance and diversity of soil fauna (Gama-Rodrigues et al., 2008; Manhães et al., 2013), as well as for the chemical properties, such as the increasing content of carbon and nitrogen, the cation exchange capacity (CEC), and the promotion of nutrient cycling (Gama-Rodrigues et al., 2008; Costa et al., 2014).
Changes in soil physical properties are hardly detectable, thus further studies are still required to improve the assessment of soil physical quality. For this purpose, Imhoff et al. (2002) stated that the tensile strength (TS) of soil aggregates is sensitive to changes in the degree of compaction. Consequently, TS may correlate with growing plant roots and their distribution in the soil and can be a useful indicator of soil quality (Carrizo et al., 2018).

The tensile strength of soil aggregates is defined by Dexter \& Watts (2000) as the force per unit area required to cause aggregate rupture. It is an extremely sensitive variable for the assessment of soil structural condition. TS is determined by a simple test, in a wide range of aggregate sizes, which improves its statistical confidence. According to TS values, the soil quality is reached when aggregates are small enough to allow of the formation of a friable seeding layer after soil preparation, but large enough to support the weight of heavy equipment with a minimum compaction (Lehrsch et al., 2012; Barbosa \& Ferraz, 2020). The surface layer of an Argissolo Vermelho-Amarelo (Typic Hapludult) under annual crops showed TS values lower than those observed under natural pasture or natural vegetation, according to Reis et al. (2014b).

Carrizo et al. (2018) obtained TS values for a Chernossolo Argilúvico (Typic Argiudoll) lower than values observed in a Chernossolo Háplico (Typic Hapludoll), and TS values higher for wheat cover than in uncovered soils. In these two soils, the results were associated with the intensity and frequency of soil wetting/drying cycles, soil structural changes resulting from the mechanized cultivation, and a content increase of aggregating agents such as total organic carbon, carbon associated with minerals, carbon of the coarse fraction, total carbohydrates, and total glomalin-related soil protein. All these factors increased the TS values.

The objective of this work was to assess the efficiency of revegetation with forest leguminous species, for the recovery of the physical quality of a Typic Hapludult under degraded pasture, located in a steep-slope tropical landscape in Southeastern Brazil.

\section{Materials and Methods}

The experimental area was located in the municipality of Conceição de Macabú, in the northern Rio de Janeiro 
state $\left(21^{\circ} 37^{\prime} \mathrm{S}\right.$ and $\left.42^{\circ} 05^{\prime} \mathrm{W}\right)$, Brazil. According to the Köppen-Geiger's classification, the regional climate corresponds to the hot and humid Am type, with $26^{\circ} \mathrm{C}$ mean annual temperature and 1,400 $\mathrm{mm}$ mean annual rainfall (Gama-Rodrigues et al., 2008; Gomes et al., 2018). The relief is characterized by steep slopes, and the studied area has about $35 \%$ steepness. The soils developed from Precambrian igneous rocks, and the soil of the experimental area is classified as Argissolo Vermelho-Amarelo distrófico típico according to the Brazilian soil classification system (Santos et al., 2018). This soil corresponds to a Typic Hapludult in the Soil Taxonomy (Soil Survey Staff, 2014), and to a Haplic Acrisol (Alumic, Clayic, Cutanic, Differentic, Profondic, Vetic), in the World Reference Base for Soil Resources (IUSS Working Group WRB, 2015).

The experimental area comprises five different vegetation types at the same elevation and steepness. Three of them were covers of leguminous trees planted in specific plots, in order to promote the improvement of soil physical conditions in degraded pasture areas: Acacia auriculiformis (northern black wattle), $M$. caesalpiniifolia ("sabiá"), and Inga edulis Mart. ("ingá"). The two other covers were a secondary forest (termed "capoeira") and a remaining degraded pasture. In the present study, the forest was taken as a reference of preserved area, as it has been unmanaged in the last 50 years (without harvesting trees or other significant anthropic interventions). The pasture was implemented around the 1930's to replace a coffee plantation and was taken here as a reference of a degraded area, as it had different types of spontaneous grasses and weeds, and it is not technically managed (no tillage, no fertilizer applications, no erosion control, infrequent weeding, no paddock subdivisions, no cattle trampling control, soil surface partially uncovered by grasses). The three leguminous species were planted in 1998, in plots of $1,500 \mathrm{~m}^{2}(75 \times 20 \mathrm{~m})$, in a $3 \times 2 \mathrm{~m}$ spacing. These plants were individually fertilized in the pit with $150 \mathrm{~g}$ of simple superphosphate (about $12 \mathrm{~g} \mathrm{P}$, $15 \mathrm{~g} \mathrm{~S}$, and $24 \mathrm{~g} \mathrm{Ca}$ ) and $10 \mathrm{~g}$ of potassium chloride (about $5 \mathrm{~g} \mathrm{~K}$ ). The tree seedlings were inoculated with specific nitrogen-fixing bacteria strains - BR 3465 and BR 3609 for A. auriculiformis, and BR 3407 and BR 3446 for M. caesalpiniifolia -, and the mycorrizhal fungi Gigaspora margarita and Glomus clarum for all leguminous trees.
Soil samples were collected in July 2015 , at $0-0.10$ and $0.10-0.20 \mathrm{~m}$ depth. In each plot, six collection points (replicates) at $5 \mathrm{~m}$ distance from each other were defined along the steepest direction. Undisturbed samples were collected in metal rings (49 $\mathrm{mm}$ diameter, $53 \mathrm{~mm}$ height, and $100 \mathrm{~cm}^{3}$ volume) inserted in the protective jacket of an impact soil sampler. The total of 240 rings were sampled for the experimental area, with 48 rings per vegetation type (four rings per soil layer, at each collection point). A soil sample with preserved natural aggregates was also collected by excavation at each soil layer, and each collection point. These aggregates samples were packed in rigid plastic containers, totalizing 12 samples per vegetation type, and 60 samples per experimental area. Finally, again by excavation, a third type of soil sample was obtained at each layer of soil, at each collection point; this sample had a disturbed structure, and also totaled the same number of samples (60) per experimental area.

Soil samples with both disturbed and undisturbed (in metal rings) structure were used by Gomes et al. (2018) for both chemical and physical characterization of soil according to Teixeira et al. (2017) (Table 1). Soil samples with preserved natural aggregates were used in the present work, as below described.

For TS determination, samples containing aggregates were air dried and slightly sieved through a $19 \mathrm{~mm}$ sieve. Aggregates retained in this sieve were manually cracked and carefully converted into smaller units, until all material had passed through the $19 \mathrm{~mm}$ mesh. Despite the application of artificial mechanical stress, this method does not affect the structure or tensile strength of air-dried samples (Oliveira et al., 2020). After that, the samples were slightly sieved through a $12.5 \mathrm{~mm}$ sieve and, then, through an $8 \mathrm{~mm}$ sieve, allowing of the separation of aggregates into two different diameter size classes: $12.5-19.0 \mathrm{~mm}$ and 8.0-12.5 $\mathrm{mm}$, respectively. Only these size ranges were selected because they represent the typical aggregates fragmented after soil preparation, in which the seed bed is established before the emergency of seedlings (Dexter, 1988).

From each sampling point, 70 aggregates (35 per layer) were tested, comprising 420 aggregates per vegetation plot (210 per layer) and 2,100 for the experimental area (1,050 per soil layer). Before the TS determinations, the aggregates were oven dried at $65^{\circ} \mathrm{C}$ for 24 hours, for moisture standardization. Each 
aggregate was weighed and subjected to an indirect stress test in a linear electronic actuator, using 4 $\mathrm{mm} \mathrm{min}^{-1}$ constant velocity (Reis et al., 2014a, 2014b; Lima et al., 2018). For the indirect stress test, each soil aggregate was positioned between a fixed metal plate at a lower position, and a mobile metal plate at upper position, attached to a $20 \mathrm{kgf}$ capacity load cell. An increasing force was applied until the tensile rupture of the aggregate, and the force variation registered each second. The tensile strength was then calculated according to Dexter \& Kroesbergen (1985):

$$
\mathrm{TS}=0.576^{\mathrm{P}} / \mathrm{D}^{2},
$$

in which: 0.576 is a proportionality constant that reflects the relationship between the compressive stress applied and the tensile stress generated within the aggregate; $\mathrm{P}$ is the force $(\mathrm{N})$ applied at the moment of rupture of aggregates; and D is the effective diameter (m) of each aggregate.

The effective aggregate diameters was calculated according to the equation proposed by Watts \& Dexter (1998), as follows:

$$
\mathrm{D}=\mathrm{D}_{\mathrm{m}}\left(\mathrm{M} / \mathrm{M}_{0}\right)^{1 / 3}
$$

in which: $\mathrm{M}$ is the mass ( $\mathrm{g}$ ) of each individual aggregate; $\mathrm{M}_{0}$ is the mean mass ( $\mathrm{g}$ ) of all aggregates evaluated in a particular size-class; and Dm is the mean diameter (mm) of aggregates (mm). Dm was assumed to be the average mesh diameter of the two sieves used to select them, that is $10.25 \mathrm{~mm}$ for the $8.0-12.5 \mathrm{~mm}$ size class (TS 8), and $15.75 \mathrm{~mm}$ for the $12.5-19.0 \mathrm{~mm}$ size class (TS 12.5).

The statistical analysis was performed assuming a completely randomized design (Gama-Rodrigues et al., 2008; Costa et al., 2014; Gomes et al., 2018). The treatments were considered in a scheme of subdivided plots, with the vegetation covers (vegetation types) as plots, the two layers of soil sampling as subplots, and the collection points as replicates (Carrizo et al., 2018). The Assistat software (Silva, 2014) was used to perform the analyses, including the experimental variance, the means comparison by Tukey's test, at 5\% probability, and the Pearson's correlation analysis. The correlation analysis was performed separately for each studied soil depth, to compare the TS values with soil physical and chemical properties, by using both the whole data set $(\mathrm{n}=30)$ and a partial data set obtained by the exclusion of the pasture $(n=24)$, in order to

Table 1. Chemical and physical soil properties under different vegetation covers, at the $0-0.10$ and $0.10-0.20 \mathrm{~m}$ soil depths of an Argissolo Vermelho-Amarelo distrófico típico (Typic Hapludult), in the municipality of Conceição de Macabú, in the

\begin{tabular}{|c|c|c|c|c|c|c|c|c|c|c|c|c|c|c|}
\hline \multirow[t]{2}{*}{$\begin{array}{l}\text { Vegetation } \\
\text { cover }\end{array}$} & $\begin{array}{c}\mathrm{pH} \\
\left(\mathrm{H}_{2} \mathrm{O}\right)\end{array}$ & $\begin{array}{c}\mathrm{P} \\
\left(\mathrm{mg} \mathrm{kg}^{-1}\right)\end{array}$ & $\begin{array}{c}\mathrm{C} \\
---(\mathrm{g} \mathrm{kg}\end{array}$ & $\begin{array}{c}\mathrm{N} \\
\left.\mathrm{r}^{-1}\right)--- \\
\end{array}$ & SB & $\begin{array}{c}\mathrm{Al} \\
\mathrm{mol}_{\mathrm{c}} \mathrm{k}\end{array}$ & $\begin{array}{c}\mathrm{H}+\mathrm{Al} \\
-1)----\end{array}$ & Sand & $\begin{array}{c}\text { Silt } \\
\left(\mathrm{g} \mathrm{kg}^{-1}\right)\end{array}$ & Clay & $\begin{array}{c}\mathrm{BD} \\
\left(\mathrm{Mg} \mathrm{m}^{-3}\right)\end{array}$ & TP & $\begin{array}{l}\text { Macro } \\
\left(\mathrm{m}^{3} \mathrm{~m}^{-3}\right)\end{array}$ & Micro \\
\hline & \multicolumn{14}{|c|}{$0-0.10 \mathrm{~m}$ soil depths } \\
\hline "Capoeira" & 4.22 & 1.83 & 18.76 & 1.56 & 0.79 & 1.13 & 7.82 & 640.0 & 85.5 & 274.5 & 1.11 & 0.58 & 0.39 & 0.18 \\
\hline Pasture & 4.26 & 3.35 & 13.08 & 0.93 & 0.41 & 0.85 & 6.40 & 637.6 & 90.7 & 271.7 & 1.36 & 0.48 & 0.24 & 0.22 \\
\hline Acacia auriculiformis & 4.48 & 2.55 & 14.59 & 1.37 & 2.14 & 0.37 & 6.77 & 627.1 & 70.1 & 302.8 & 1.38 & 0.47 & 0.32 & 0.22 \\
\hline Inga edulis & 4.22 & 2.18 & 13.90 & 1.07 & 0.90 & 0.98 & 6.55 & 610.8 & 93.1 & 296.1 & 1.21 & 0.54 & 0.29 & 0.23 \\
\hline \multirow[t]{2}{*}{ Mimosa caesalpiniifolia } & 4.26 & 2.63 & 15.98 & 1.36 & 1.05 & 1.17 & 7.77 & 603.8 & 96.8 & 299.4 & 1.25 & 0.52 & 0.22 & 0.26 \\
\hline & \multicolumn{14}{|c|}{$0.10-0.20 \mathrm{~m}$ soil depths } \\
\hline "Capoeira" & 4.12 & 1.18 & 12.15 & 1.10 & 0.30 & 1.12 & 7.48 & 598.6 & 93.8 & 307.6 & 1.09 & 0.58 & 0.35 & 0.23 \\
\hline Pasture & 4.18 & 0.63 & 11.26 & 0.86 & 0.16 & 0.92 & 7.07 & 533.3 & 110.2 & 356.5 & 1.27 & 0.52 & 0.17 & 0.26 \\
\hline Acacia auriculiformis & 4.34 & 1.63 & 11.07 & 1.00 & 0.79 & 0.88 & 6.62 & 510.0 & 96.0 & 394.0 & 1.47 & 0.44 & 0.24 & 0.27 \\
\hline Inga edulis & 4.28 & 1.25 & 10.82 & 1.01 & 0.40 & 1.08 & 6.57 & 535.7 & 108.3 & 356.0 & 1.28 & 0.51 & 0.19 & 0.29 \\
\hline Mimosa caesalpiniifolia & 4.22 & 1.43 & 11.94 & 1.00 & 0.46 & 1.23 & 6.65 & 515.4 & 111.7 & 372.9 & 1.37 & 0.48 & 0.26 & 0.25 \\
\hline
\end{tabular}
state of Rio de Janeiro, Brazil(1).

${ }^{(1)} \mathrm{pH}$ in water (1:2.5); $\mathrm{P}$, phosphorus extracted using Mehlich-1 solution; $\mathrm{C}$, organic carbon determined after oxidations with $\mathrm{K}_{2} \mathrm{Cr}_{2} \mathrm{O}_{7}$ and determined by titration with $\mathrm{Fe}\left(\mathrm{NH}_{4}\right)_{2}\left(\mathrm{SO}_{2}\right) \cdot 6 \mathrm{H}_{2} \mathrm{O} ; \mathrm{N}$, total $\mathrm{N}$ determined by the Kjeldahl method; $\mathrm{SB}$, sum of bases; Al, aluminum extracted with 1 mol $\mathrm{L}^{-1} \mathrm{KCl}$ solution; $\mathrm{H}+\mathrm{Al}$, extracted with $0.5 \mathrm{~mol} \mathrm{~L}{ }^{-1}$ calcium acetate solution; sand, by sieving through $53 \mu \mathrm{m}$; silt, by subtraction of sand and clay contents; clay, by pipette method; BD, soil bulk density, TP, total porosity; Macro, macropores diameter $\geq 50 \mu \mathrm{m}$; and Micro, micropores diameter $\leq 50 \mu \mathrm{m}$. Note: The analyses were carried out by Gomes et al. (2018) according to Teixeira et al. (2017). 
exclude any particular effect of grass root system on the mechanical attributes of soil aggregates.

\section{Results and Discussion}

Results for TS 8 and TS 12.5 measurements showed that, in general, the TS 8 values were higher than those for TS 12.5 (Table 2). At the $0-0.10 \mathrm{~m}$ soil depths, the overall mean of TS 12.5 was $33.7 \mathrm{kPa}$ (with mean values for the vegetation covers ranging from 22.7 to $46.0 \mathrm{kPa}$ ), while the overall mean for TS 8 was $47.3 \mathrm{kPa}$ (mean values ranging from 37.1 to $62.2 \mathrm{kPa}$ ), which is $40 \%$ higher than the overall mean of TS 12.5. At the $0.10-$ $0.20 \mathrm{~m}$ soil depths, the overall mean of TS 12.5 was $35.8 \mathrm{kPa}$ (mean TS ranged from 22.8 to $51.4 \mathrm{kPa}$ ), while the overall mean for TS 8 was $47.0 \mathrm{kPa}$ (ranging from 39.2 to 53.0 ), which is $31 \%$ higher than that of TS 12.5 . The intra-aggregate fault zones are transmitted through the aggregate under the application of high tensions, and this process increases proportionally to the size of aggregates. Thus, lower TS values are necessary to disrupt the biggest aggregates (Oliveira et al., 2020).

The above-mentioned mean values are compatible with the TS variation commonly observed for aggregates of $12.5-19.0 \mathrm{~mm}$ size diameter collected from superficial layers of tropical soils. In Brazilian Latossolos (Oxisols), reported values include TS mean values of $49.4 \mathrm{kPa}$ under pasture cover (Imhoff et al., 2002), mean values of $30 \mathrm{kPa}$ under forest, and $75 \mathrm{kPa}$ under crop cover (Tormena et al., 2008b). In these soil types, mean TS values are reported to be $30 \mathrm{kPa}$ in a grazing area and $52 \mathrm{kPa}$ in a no-tillage system (Bavoso et al., 2010), and a range of 64-92 kPa under croplivestock system, whose values vary according to the specific system of animal management (Guimarães et al., 2009). In another Argissolo Vermelho-Amarelo distrófico (Typic Hapludult, the same soil class studied in the present work), TS means ranged from $75 \mathrm{kPa}$ under fallow to $88 \mathrm{kPa}$ under pasture (Lima et al., 2018).

For the TS 8 measurements, there was no statistical interaction between the treatment factors (vegetation cover and soil layer), and no statistical differences between the two soil depths studied $(0-0.10$ and 0.10 $0.20 \mathrm{~m}$ layer). By comparing the vegetation covers, samples from "capoeira" site show the highest TS 8 values, which were statistically similar to those of two other forest covered sites ("ingá" and "sabiá"). The samples from pasture site showed the lowest TS 8 values, but statically comparable to northern black wattle site (Table 2).

For the TS 12.5 measurements, there was no statistical difference between layers for pasture and "ingá" sites. In the "capoeira" site, the highest TS 12.5 value was at the $0-0.10 \mathrm{~m}$ soil depths, and in the northern black wattle and "sabiá" sites the inverse occurred, with the highest TS 12.5 values at the $0.10-0.20 \mathrm{~m}$ soil depths. The "sabiá" site showed distinctly high mean values at the $0.10-0.20 \mathrm{~m}$ soil depths, while those from pasture site were statistically lower than the ones from the other

Table 2. Tensile strength (TS) of aggregates, for the different vegetation covers and soil depths of an Argissolo VermelhoAmarelo distrófico típico (Typic Hapludult), in the municipality of Conceição de Macabú, in the state of Rio de Janeiro, Brazil $^{(1)}$.

\begin{tabular}{|c|c|c|c|c|c|c|}
\hline \multirow{2}{*}{$\begin{array}{l}\text { Vegetation } \\
\text { cover }\end{array}$} & TS $8(\mathrm{kPa})$ & TS $12.5(\mathrm{kPa})$ & $\mathrm{TS} 8(\mathrm{kPa})$ & TS $12.5(\mathrm{kPa})$ & TS $8(\mathrm{kPa})$ & TS $12.5(\mathrm{kPa})$ \\
\hline & \multicolumn{2}{|c|}{$0-0.10 \mathrm{~m}$ soil depths } & \multicolumn{2}{|c|}{$0.10-0.20 \mathrm{~m}$ soil depths } & \multicolumn{2}{|c|}{$0-0.20 \mathrm{~m}$ soil depths (average of depths) } \\
\hline "Capoeira" & 62.2 & $37.8 \mathrm{aA}$ & 51.2 & $30.3 \mathrm{bcB}$ & $56.7 \mathrm{a}$ & 34.1 \\
\hline Pasture & 37.1 & $22.7 \mathrm{bA}$ & 39.2 & $22.8 \mathrm{cA}$ & $37.6 \mathrm{c}$ & 22.8 \\
\hline Acacia auriculiformis & 41.7 & $24.7 \mathrm{bB}$ & 42.0 & $36.3 \mathrm{bA}$ & $41.9 \mathrm{bc}$ & 30.5 \\
\hline Inga edulis & 49.0 & $37.1 \mathrm{aA}$ & 49.3 & $38.1 \mathrm{bA}$ & $49.1 \mathrm{ab}$ & 37.6 \\
\hline Mimosa caesalpiniifolia & 47.4 & $46.0 \mathrm{aB}$ & 53.0 & $51.4 \mathrm{aA}$ & $50.2 \mathrm{ab}$ & 48.7 \\
\hline Average & $47.29 \mathrm{~A}$ & 33.66 & $46.98 \mathrm{~A}$ & 35.82 & 47.14 & 34.7 \\
\hline
\end{tabular}

${ }^{(1)}$ TS 8 and TS 12.5 , tensile strength obtained in aggregates of the size-classes $8.0-12.5 \mathrm{~mm}$ and $12.5-19.0 \mathrm{~mm}$, respectively. The statistical interaction between vegetation cover and soil layer was not significant for TS 8, but it was significant for TS 12.5. Means followed by equal letters, uppercases in the comparison of layers (in the lines), and lowercases in the comparison of vegetation covers (in the columns) do not differ by the Tukey's test, at $5 \%$ probability. The Coefficients of variation obtained in the analysis of variance for TS 8 and TS 12.5 were respectively $18.36 \%$ and $19.46 \%$ in the plots, and $14.75 \%$ and $20.93 \%$ in the subplots. 
coverages, except for the "capoeira" site mean values. For the $0-0.10 \mathrm{~m}$ soil layer, the same trend is observed: samples from the "sabiá" site are distinctly high, but grouped with those from "ingá" and "capoeira" sites, while samples from the pasture site have the lowest TS 12.5 values, although statistically comparable to those of northern black wattle samples (Table 2).

The vegetation covers affected the TS values of soil aggregates, despite the great morphological uniformity (color, structure, and consistency) existing among the surface A horizons of the five studied Argissolo Vermelho-Amarelo distrófico típico (Typic Hapludult) profiles. This result evidences that TS is a variable significantly affected by soil use and management and, therefore, shows that it is a potential indicator of soil quality (Imhoff et al., 2002; Reis et al., 2014a). However, the use of a single variable to assess the soil physical quality may be an oversimplification, as the interactions are very complex among the various factors and mechanisms involved in the soil aggregation.
The aggregate TS values are supposed to increase as a response to the physical proximity of soil individual particles, which reduces the intra-aggregate space and leads to a reduction of the number and thickness of cracks. This assumption is confirmed in several studies (Tormena et al., 2008b; Lima et al., 2018), whose results show positive correlations between TS and soil bulk density (BD), and negative correlations between TS and total porosity (TP). However, these expected correlations were not clearly observed under the experimental settings of the present study, as shown by the Pearson's correlation coefficients (Table 3).

Results for the $0-0.10 \mathrm{~m}$ soil layer, in the two aggregate classes (TS 8 and TS 12.5), show that the correlations were significant, but with an opposite trend in relation to the expected correlations (negative with soil density and microporosity, and positive with TP and macroporosity) (Table 3). For the $0.10-0.20 \mathrm{~m}$ soil layer, TS 8 results did not correlate significantly with the density or other soil attributes related to the structure (total porosity and its fractions). Only for the TS 12.5, measured in the larger aggregates of this layer,

Table 3. Coefficients of the Pearson's linear correlation (r) between both tensile strengths TS 8 and TS 12.5 (obtained in aggregates of the size-classes $8.0-12.5 \mathrm{~mm}$ and $12.5-19.0 \mathrm{~mm}$, respectively), and other soil chemical and physical properties (at the $0-0.10$ and $0.10-0.20 \mathrm{~m}$ soil depths) under different vegetation covers, in the municipality of Conceição de Macabú, in the state of Rio de Janeiro, Brazil ${ }^{(1)}$.

Variable


the correlations occurred as expected, that is, they were positive between soil density and microporosity, and negative between TP and macroporosity. From the general evaluation of the described results, the predominance of atypical correlations was verified among TS and other physical variables linked to the soil structure.

In addition to the aforementioned correlation analysis, the mean values show that samples from the pasture site showed the lowest TS values for the two aggregate classes, despite the high $\mathrm{BD}$ values, while the highest TS values occurred in the "capoeira" site, despite the lowest BD values observed for this cover (Tables 1 and 2). The contrasting TS results of pasture and "capoeira" sites could be justified by other factors besides soil compactness. In both sites, the amount of fine roots at the two soil depths was described as similar. The root growth inside the aggregates is usually responsible for an increase of the intra-aggregate porosity, which works as weakness zones that reduce the TS values (Reis et al., 2014b). Assuming that the fasciculate root system of grasses has a high efficiency to grow inside the aggregates and create intra-aggregates cracks, we can suppose that it may promote the reduction of their rupture resistance (Tormena et al., 2008a), which would justify the lowest TS values found in the pasture site. Conversely, the root growing in the inter-aggregate zones may involve and pressure the aggregates, leading to an increase of the TS values (Lima et al., 2018) without affecting the $\mathrm{BD}$ values of the bulk soil.

Fine roots of a pivotal root system preferentially growing in the inter-aggregate zones rather than inside aggregates could explain the highest TS values in the samples from the "capoeira" site. In addition, the water uptake by plant roots is uneven inside the soil matrix, which leads to a nonuniform distribution of moisture in space and time. For root-penetrated aggregates, these spatially differentiated wetting/drying cycles increase the occurrences of new weakness intra-aggregates zones, which are responsible for an additional reduction of TS values (Guimarães et al., 2009), and that were possibly more pronounced in the soil under pasture.

Below are the results of an alternative linear correlation analysis, that was performed by excluding the pasture data and considering only the data related to the soil under the four studied forest covers $(n=24)$. For the $0-0.10 \mathrm{~m}$ soil layer without the pasture, TS 8 and TS 12.5 still remained negatively correlated with $\mathrm{BD}\left(\mathrm{r}=-0.56^{* *}\right.$ and $\mathrm{r}=-0.38^{\text {ns }}$, respectively), although no longer significant for TS 12.5 data. For the samples from the $0.10-0.20 \mathrm{~m}$ soil layer, the correlation patterns did not change either, as TS 8 showed negative and nonsignificant correlations between TS and other soil structural variables $\left(\mathrm{r}=-0.29^{\mathrm{ns}}\right.$ for $\mathrm{BD}$ and $\left.\mathrm{TP}\right)$, and TS 12.5 showed correlations that were positive and significant with some structural attributes, such as BD $\left(\mathrm{r}=0.44^{*}\right)$ and microporosity $\left(\mathrm{r}=0.71^{* *}\right)$, and negative with total porosity $\left(\mathrm{r}=-0.44^{*}\right)$ and macroporosity $\left(\mathrm{r}=-0.55^{* *}\right)$. These results are pretty similar to those above described for the full correlation analysis (n $=30$ ), which did not lead to the expected positive correlation between TS and BD values (Tormena et al., 2008b; Lima et al., 2018), and, therefore do not confirm possible and peculiar effects of dense fine root system of grasses on the mechanical attributes of soil aggregates.

Although not confirmed by the above mentioned analysis, effects of the fasciculate root system of grasses on the aggregate mechanical attributes cannot be excluded, since in the areas under legumes, where TS values were intermediate between pasture and "capoeira" (Table 2), the effects may have been inherited from the period prior to revegetation, when the area was completely occupied by pasture.

TS results can be also interpreted in the light of the variations of other soil attributes. TS 8 and TS 12.5 values are somewhat correlated with other attributes that promote soil aggregation (Table 3). There are positive correlations with the clay content, and negative ones with sand, silt, dispersed clay contents, and with the degree of clay flocculation. As to the chemical properties, the correlations were positive with several attributes, such as exchangeable ( $\mathrm{Al}, \mathrm{Mg}, \mathrm{K}$ ) or potential acidity covalent $(\mathrm{H}+\mathrm{Al})$ cations, effective $\mathrm{CEC}$, and $\mathrm{C}$ content.

The positive correlations of TS with the soil C content and, by inference, with the soil organic matter (SOM) content of the present study corroborate those by other authors described as follows. Guimarães et al. (2009) and Reis et al. (2014b) found a positive correlation between TS and SOM values. These positive correlations can be explained by the following complementary processes: specific organomineral interactions at a colloidal level (Imhoff et al., 2002; Tormena et al., 2008b); and by the incorporation of 
SOM in the microporosity, which favors the physical stabilization of the microaggregates that form large aggregates. Moreover, other studies have found that the correlations between SOM and TS may not be significant (Imhoff et al., 2002; Tormena et al., 2008a) or even negative (Tormena et al., 2008b; Lima et al., 2018), which can be explained by the recognized role of SOM in increasing soil porosity, promoting the increase of the distance between soil particles and, thus, diluting the effect of its aggregating force. Therefore, the effect of SOM in the TS of aggregates is controversial, depending on the balance between these two opposing effects.

Gomes et al. (2018) studied the same experimental area at the same moment of the present study, and they found that soil organic carbon (SOC) content under the "sabiá" site $\left(16.0 \mathrm{~g} \mathrm{~kg}^{-1}\right)$ was the only one statistically equivalent to that of "capoeira" site (18.8 $\left.\mathrm{g} \mathrm{kg}^{-1}\right)$ (Table 1). These results would allow the interpretation that the highest values of TS of aggregates in the "sabiá" site are functionally associated with the higher levels of SOM. However, a closer look at the results of the Pearson's correlation analysis (Table 3) shows that this direct relationship between SOM and tensile strength is not well established, since the positive correlation between TS values and $\mathrm{C}$ content was only significant for TS 8 at the $0-0.10 \mathrm{~m}$ soil depths. For the other data (TS 8 in the $0-0.10 \mathrm{~m}$ soil layer, and TS 12.5 in the two layers), there were no significant correlations, which would corroborate the results found by Imhoff et al. (2002) and Tormena et al. (2008a). The absence of a clear trend emphasizes the dual effect of SOM in the aggregate resistance.

Costa et al. (2014) also studied the same experimental area, before the present study, and found that the litter inputs $\left(\mathrm{Mg} \mathrm{ha}^{-1}\right.$ per year) were higher under the "sabiá" cover (5.35), and lower under "capoeira" (2.65), with northern black wattle in an intermediate position (4.39), which suggests that the higher litter turnover rates can be an aspect to be taken in account for increasing aggregate resistance.

Still in relation to the higher TS values of aggregates in the "sabiá" site, the litter turnover rates and its chemical quality, obtained by Costa et al. (2014) before the present study for the same experimental area, could be also taken into account. These authors found that litter inputs ( $\mathrm{Mg} \mathrm{ha}^{-1}$ per year) were higher under "sabiá" (5.35), and lower under "capoeira" (2.65), with the northern black wattle cover in an intermediate position (4.39), and "sabiá" litter showing the lower polyphenols, lignin, and cellulose content. According to Carrizo et al. (2018), some organic compounds acting as aggregating agents (like glomalin-related proteins) may increase the TS values. In the present study, the differences in the composition of residue incorporated by the five vegetation covers, as well as produced during litter decomposition, probably affected the TS in different ways. Although speculative, this hypothesis helps to explain this controversial trend.

\section{Conclusions}

1. Land revegetation with the leguminous trees northern black wattle (Acacia auriculiformis), "ingá" (Inga edulis), and mainly "sabiá" (Mimosa caesalpiniifolia) recovers somehow the soil physical quality, since the tensile strength values are predominantly closer to those of the secondary forest than to those of the degraded pasture.

2. Highly stable aggregates can prevail even in manifestly porous soils, which is corroborated by forest showing higher tensile strength of aggregates and higher soil porosity.

3. Weakly stable aggregates can prevail in clearly densified soils, such as the soil under the pasture that showed the lowest values for tensile strength of aggregates and highest soil bulk density.

4. The tensile strength of aggregates correlates with physical and chemical attributes that promote soil aggregation.

\section{Acknowledgments}

To Coordenação de Aperfeiçoamento de Pessoal de Nível Superior (Capes, Finance Code 001), for the Proap financial support to the Plant Production PostGraduation Program of Universidade Estadual do Norte Fluminense Darcy Ribeiro (Uenf); to Fundação Carlos Chagas Filho de Amparo à Pesquisa do Estado do Rio de Janeiro (Faperj, Process no. E-26/100.608/2014), for the doctoral scholarship to first author; and to Mr. José Laércio Paixão Flores, owner of the Carrapeta Farm, for permitting the collection of soil samples and, even more, for the revegetation of the studied area. 


\section{References}

BARBOSA, L.A.P.; FERRAZ, A.C. de O. Which evidence attests for soil aggregate rupture? A new criterion to determine aggregate tensile strength. Soil \& Tillage Research, v.197, art. 104530, 2020. DOI: https://doi.org/10.1016/j.still.2019.104530.

BAVOSO, M.A.; GIAROLA, N.F.B.; TORMENA, C.A.; PAULETTI, V. Preparo do solo em áreas de produção de grãos, silagem e pastejo: efeito na resistência tênsil e friabilidade de agregados. Revista Brasileira de Ciência do Solo, v.34, p.227-234, 2010. DOI: https://doi.org/10.1590/S0100-06832010000100023.

CARDOSO, E.J.B.N.; VASCONCELLOS, R.L.F.; BINI, D.; MIYAUCHI, M.Y.H.; SANTOS, C.A. dos; ALVES, P.R.L.; PAULA, A.M. de; NAKATANI, A.S.; PEREIRA, J. de M.; NOGUEIRA, M.A. Soil health: looking for suitable indicators. What should be considered to assess the effects of use and management on soil health? Scientia Agricola, v.70, p.274-289, 2013. DOI: https://doi.org/10.1590/S0103-90162013000400009.

CARRIZO, M.E.; ALESSO, C.A.; SOARES FRANCO, H.H.; BERNABÉ FERREIRA, C.J.; IMHOFF, S. Tensile strength of mollisols of contrasting texture under influence of plant growth and crop residues addition. Geoderma, v.329, p.1-10, 2018. DOI: https://doi.org/10.1016/j.geoderma.2018.04.024.

COSTA, M.G. da; GAMA-RODRIGUES, A.C. da; ZAIA, F.C.; GAMA-RODRIGUES, E.F. da. Leguminosas arbóreas para recuperação de áreas degradadas com pastagem em Conceição de Macabu, Rio de Janeiro, Brasil. Scientia Forestalis, v.42, p.101112, 2014.

DEXTER, A.R. Advances in characterization of soil structure. Soil \& Tillage Research, v.11, p.199-238, 1988. DOI: https://doi.org/10.1016/0167-1987(88)90002-5.

DEXTER, A.R.; KROESBERGEN, B. Methodology for determination of tensile strength of soil aggregates. Journal of Agricultural Engineering Research, v.31, p.139-147, 1985. DOI: https://doi.org/10.1016/0021-8634(85)90066-6.

DEXTER, A.R.; WATTS, C.W. Tensile strength and friability. In: SMITH, K.A.; MULLINS, C.E. (Ed.). Soil and environmental analysis: physical methods. $2^{\text {nd }}$ ed. rev. and expand. New York: Marcel Dekker, 2000. p.405-433.

GAMA-RODRIGUES, E.F. da; GAMA-RODRIGUES, A.C. da; PAULINO, G.M.; FRANCO, A.A. Atributos químicos e microbianos de solos sob diferentes coberturas vegetais no norte do Estado do Rio de Janeiro. Revista Brasileira de Ciência do Solo, v.32, p.1521-1530, 2008. DOI: https://doi.org/10.1590/S010006832008000400016 .

GOMES, D.S.; MARCIANO, C.R.; FAUSTINO, L.L. Physical quality of a Typic Hapludult soil under forest leguminous trees and pasture. Floresta e Ambiente, v.25, e20170400, 2018. DOI: https://doi.org/10.1590/2179-8087.040017.

GUIMARÃES, R.M.L.; TORMENA， C.A.; ALVEZ, S.J.; FIDALSKI, J.; BLAINSKI, É. Tensile strength, friability and organic carbon in an Oxisol under a crop-livestock system. Scientia Agricola, v.66, p.499-505, 2009. DOI: https://doi.org/10.1590/S0103-90162009000400011.
IMHOFF, S.; SILVA, A.P. da; DEXTER, A. Factors contributing to the tensile strength and friability of Oxisols. Soil Science Society of America Journal, v.66, p.1656-1661, 2002. DOI: https://doi.org/10.2136/sssaj2002.1656.

IUSS WORKING GROUP WRB. World Reference Base for Soil Resources 2014: International soil classification system for naming soils and creating legends for soil maps: update 2015. Rome: FAO, 2015. (FAO. World Soil Resources Reports, 106). Available at: <http://www.fao.org/3/i3794en/I3794en.pdf $>$. Accessed on: May 222020.

LEHRSCH, G.A.; SOJKA, R.E.; KOEHN, A.C. Surfactant effects on soil aggregate tensile strength. Geoderma, v.189-190, p.199206, 2012. DOI: https://doi.org/10.1016/j.geoderma.2012.06.015.

LIMA, C.L.R. de; PAIVA, R.B. de; NUNES, M.C.M.; TUCHTENHAGEN, I.K.; PILLON, C.N. Critical values of physical attributes of an Ultisol under uses in South of Brazil. Revista Brasileira Ciências Agrárias, v.13, e5529, 2018. DOI: https://doi.org/10.5039/agraria.v13i2a5529.

MANHÃES, C.M.C.; GAMA-RODRIGUES, E.F.; MOÇO, M.K.S.; GAMA-RODRIGUES, A.C. Meso- and macrofauna in the soil and litter of leguminous trees in a degraded pasture in Brazil. Agroforestry Systems, v.87, p.993-1004, 2013. DOI: https://doi.org/10.1007/s10457-013-9614-0.

OLIVEIRA, L. DE S.; MAIA, R.N.; ASSIS JÚNIOR, R.N. de; ROMERO, R.E.; COSTA, M.C.G.; ALENCAR, T.L. de; MOTA, J.C.A. Tensile strength values for the degrees of soil consistency using human perception and TS-Soil device. Catena, v.190, art.104541, 2020. DOI: https://doi.org/10.1016/j. catena.2020.104541

PRETY, J.; BHARUCHA, Z.P. Sustainable intensification in agricultural systems. Annals of Botany, v.114, p.1571-1596, 2014. DOI: https://dx.doi.org/10.1093\%2Faob\%2Fmcu205.

REIS, D.A.; LIMA, C.L.R. de; PAULETTO, E.A. Resistência tênsil de agregados e compressibilidade de um solo construído com plantas de cobertura em área de mineração de carvão em Candiota, RS. Revista Brasileira de Ciência do Solo, v.38, p.669-678, 2014a. DOI: https://doi.org/10.1590/S010006832014000200031 .

REIS, D.A.; LIMA, C.L.R. de; PAULETTO, E.A.; DUPONT, P.B.; PILLON, C.N. Tensile strength and friability of an Alfisol under agricultural management systems. Scientia Agricola, v.71, p.163-168, 2014b. DOI: https://doi.org/10.1590/S010390162014000200012 .

RESENDE, A.S. de; CHAER, G.M.; CAMPELLO, E.F.C.; SILVA, A. de P.; LIMA, K.D.R. de; CURCIO, G.R. Uso de leguminosas arbóreas na recuperação de áreas degradadas. In: ARAÚJO, A.P.; ALVES, B.J.R. (Ed.). Tópicos em ciências do solo. Viçosa: Sociedade Brasileira de Ciência do Solo, 2013. v.8, p.71-92.

SANTOS, G.G.; SILVEIRA, P.M. da; MARCHÃO, R.L.; PETTER, F.A.; BECQUER, T. Atributos químicos e estabilidade de agregados sob diferentes culturas de cobertura em Latossolo do cerrado. Revista Brasileira de Engenharia Agrícola e Ambiental, v.16, p.1171-1178, 2012. DOI: https://doi.org/10.1590/ S1415-43662012001100005. 
SANTOS, H.G. dos; JACOMINE, P.K.T.; ANJOS, L.H.C. dos; OLIVEIRA, V.Á. de; LUMBRERAS, J.F.; COELHO, M.R.; ALMEIDA, J.A. de; ARAÚJO FILHO, J.C. de; OLIVEIRA, J.B. de; CUNHA, T.J.F. Sistema brasileiro de classificação de solos. 5.ed. rev. e ampl. Brasília: Embrapa, 2018. 356p. Available at: $<$ https:/ainfo.cnptia.embrapa.br/digital/bitstream/item/199517/1/ SiBCS-2018-ISBN-9788570358004.pdf>. Accessed on: May 22 2020 .

SILVA, F. de A.S. e. ASSISTAT: assistência estatística. versão 7.7 beta (pt). Campina Grande: Universidade Federal de Campina Grande, 2014. Programa computacional.

SOIL SURVEY STAFF. Keys to soil taxonomy. $12^{\text {th }}$ ed. Washington: USDA,2014.360p. Availableat: $<$ https://www.nrcs.usda.gov/wps/PA_ NRCSConsumption/download?cid=stelprdb1252094\&ext=pdf $>$. Accessed on: May 222020.
TEIXEIRA, P.C.; DONAGEMMA, G.K.; FONTANA, A.; TEIXEIRA, W.G. (Ed.). Manual de métodos de análise de solo. 3.ed. rev. e ampl. Brasília: Embrapa, 2017. 573p.

TORMENA, C.A.; ARAÚJO, M.A.; FIDALSKI, J.; IMHOFF, S.; SILVA, A.P. da. Quantificação da resistência tênsil e da friabilidade de um Latossolo Vermelho distroférrico sob plantio direto. Revista Brasileira de Ciência do Solo, v.32, p.943-952, 2008a. DOI: https://doi.org/10.1590/S0100-06832008000300004.

TORMENA, C.A.; FIDALSKI, J.; ROSSIJUNIOR, W. Resistência tênsil e friabilidade de um Latossolo sob diferentes sistemas de uso. Revista Brasileira de Ciência do Solo, v.32, p.33-42, 2008b. DOI: https://doi.org/10.1590/S0100-06832008000100004.

WATTS, C.W.; DEXTER, A.R. Soil friability: theory, measurement and the effects of management and organic carbon content. European Journal of Soil Science, v.49, p.73-84, 1998. DOI: https://doi.org/10.1046/j.1365-2389.1998.00129.x. 